\title{
ПОРУШЕННЯ ПАТЕНТНИХ ПРАВ
}

Панасюк К. Т.

У науковій статті досліджено актуальні питання щодо захисту патентних прав. Проаналізовано поняття та види порушень прав власників патенту, способи використання винаходу, корисної моделі, промислового зразка. Автором зроблено висновки щодо застосування правової презумпції вини відповідача, щодо необхідності призначення експертизи у спорах щодо захисту патентних прав, щодо дій, які не визнаються порушенням патентних прав.

Ключові слова: патент, права, винахід, корисна модель, порушення, захист, суд.

В научной статье исследованы актуальные вопросы защиты патентных прав. Проанализированы понятия и виды нарушений прав владельцев патента, способы использования изобретения, полезной модели, промышленного образца. Автором сделаны выводы относительно применения правовой презумпции вины ответчика, о необходимости назначения экспертизы по спорам о защите патентных прав, относительно действий, которые не признаются нарушением патентных прав.

Ключевые слова: патент, права, изобретение, полезная модель, нарушение, защита, суд.

The article deals with topical issues concerning the protection of patent rights. The concepts and types of infringements of the rights of the owners of the patent, methods of using the invention, utility model, industrial design are analyzed. The author makes conclusions on the application of the legal presumption of the defendant's guilt, the necessity of appointment of expertise in disputes concerning the protection of patent rights, concerning actions that are not recognized as violations of patent rights.

The law does not specify a list of violations of rights to objects of patent law. Any infringement of patent rights that are defined by law is a violation of these rights. The Laws of Ukraine "On Protection of Rights to Inventions and Utility Models" and "On the Protection of Rights to Industrial Designs" do not contain either a list of violations or definitions of the concepts of individual patent rights violations. This can be considered as a disadvantage of the legislative technique for regulating these relations. Violation of patent rights occurs when the person (infringer) uses the invention (utility model) without the consent of the respective subject of patent rights (the patent holder or his successor). Such agreement is confirmed by the contract (licensing agreement, agreement on the transfer of exclusive rights, etc.) or a license. The statutory material-legal presumption of the defendant's fault is not entirely consistent with the requirements of procedural legislation regarding the burden of proof. In patent litigation cases, in the event of a dispute between the parties, the court in each such case should appoint an examination. The issue of appointment of a judicial examination should be decided by the court only after a thorough examination of the circumstances of the case and the arguments of the parties regarding the real need for such appointment. With the help of an expert study, actual data can be established on: the novelty of the invention or the utility model, the existence of the invention of the invention level, etc.

Key words: patent, law, invention, utility model, violation, defense, court.

Постановка проблеми та іï актуальність. Патентне право включає в себе норми чинного законодавства
України щодо охорони прав на винаходи, корисні моделі і промислові зразки. Це традиційний підхід до розуміння правової природи патентного права. Натомість патентні права - це права, які випливають з патенту на винахід, корисну модель, промисловий зразок. Зокрема, ці права діють від дати публікації відомостей про видачу патенту і надають власнику патенту виключну можливість використовувати винахід, корисну модель, промисловий зразок на свій розсуд. Власне посягання інших осіб на вказану «виключність» у використанні вказаних прав і становить порушення патентних прав. Законодавство щодо регулювання цих відносин $\epsilon$ недосконалим, оскільки кількох норм, які містяться в Законі України «Про охорону прав на винаходи і корисні моделі» (та аналогічні норми Закону України «Про охорону прав на промислові зразки»), недостатньо для належного регулювання захисту патентних прав. Законодавець у вказаних законодавчих актах не визначив ні характеристики порушень патентних прав, ні спеціальних способів захисту. Натомість судова практика у цій категорії справ, яка $\epsilon$ досить поширеною, потребує саме деталізації змісту порушень, визначення особливостей доказування тощо.

Отже, станом на сьогодні актуальним для наукового дослідження залишається питання порушення патентних прав.

Аналіз останніх досліджень і публікацій. У науковій літературі відсутні монографічні дослідження з тематики дослідження. Порушення патентних прав та порядок і способи захисту цих прав було предметом дослідження окремих науковців, які здійснюють свої наукові дослідження в царині права інтелектуальної власності [1-3]. Водночас поодинокий характер таких досліджень не вирішує комплексно вказану проблематику, що вказує на актуальність даного наукового дослідження.

Метою статті $є$ здійснення на основі аналізу наукової літератури та положень нормативно-правових актів характеристики порушень патентних прав, обґрунтування пропозицій щодо вдосконалення правового регулювання цих відносин.

Виклад основного матеріалу. Види порушень патентних прав визначені у спеціальному законодавстві, яке врегульовує відносини, пов'язані з використанням винаходів, корисних моделей та промислових зразків. Зокрема, відповідно до ч. 1 ст. 34 Закону України «Про охорону прав на винаходи і корисні моделі» будь-яке посягання на права власника патенту, що передбачені ст. 28 цього Закону, вважається порушенням прав власника патенту, що тягне за собою відповідальність згідно з чинним законодавством України. Норма аналогічного змісту міститься і в Законі України «Про охорону прав на промислові зразки» (ст. 20 цього Закону).

Тобто законодавець не визначає переліку порушень прав на об'єкти патентного права, а вказує на те, що 
будь-яке посягання на патентні права, які визначені законом, є порушенням. Звертаємо увагу на те, що цей підхід законодавця відрізняється від того підходу, який міститься в Законі України «Про авторське право і суміжні права». Зокрема, ст. 50 цього закону містить перелік дій, які вважаються порушенням авторського права та суміжних права (серед яких порушення особистих немайнових прав, піратство, плагіат, розповсюдження, ввезення на митну територію України контрафактних примірників творів, камкординг, кардшейрінг та інші види порушень). При цьому визначення окремих понять, які характеризують порушення авторського права та суміжних прав, наведені у ст. 1 Закону України «Про авторське право і суміжні права».

Закони України «Про охорону прав на винаходи і корисні моделі» та «Про охорону прав на промислові зразки» не містить ні переліку порушень, ні визначення понять окремих порушень патентних прав, що можна вважати недоліком законодавчої техніки щодо регулювання вказаних відносин.

Як слушно вказують у науковій літературі, порушенням прав патентовласника визнається будь-яке використання винаходу (корисної моделі), що здійснюється без його дозволу, крім випадків, прямо передбачених законом (йдеться про дії, які не визнаються порушенням прав патентовласника, передбачені ст. 31 Закону України «Про охорону прав на винаходи і корисні моделі»: право попереднього користувача, використання без комерційної мети, з науковою метою, в порядку експерименту, за надзвичайних обставин тощо) [4; с. 255]. Такий висновок базується на аналізі статей 28, 34 Закону України «Про охорону прав на винаходи і корисні моделі».

3 цих статей вбачається, що порушення патентних прав має місце тоді коли, особа (порушник) здійснює використанням винаходу (корисної моделі) без згоди відповідного суб'єкта патентних прав (власника патенту або особи, якій ці права передано за договором чи в порядку спадкування). Таке використання трактувалося Вищим господарським судом України (далі - ВГС України) як несанкціоноване. Зокрема, як вказує ВГС України у п. 82 Постанови Пленуму № 12 від 17.10.2012 р. «Про деякі питання практики вирішення спорів, пов'язаних із захистом прав інтелектуальної власності» будь-яке несанкціоноване використання прав інтелектуальної власності на об'єкти патентних прав іншими особами $є$ встановленим фактом позадоговірного порушення патентних прав [5]. Порушення патентних прав має місце там, де порушник не отримав згоди від патентовласника (іншої особи, яка володіє цими правами) на використання певного об'єкту промислової власності. Така згода підтверджується договором (ліцензійний договір, договір про передання виключних прав тощо) або ліцензією.

Винятками з цього правила, тобто випадками, коли використання винаходу, корисної моделі, промислового зразка без згоди правовласника не буде вважатися порушенням патентних прав, $є$ використання цих об'єктів в порядку ст. 31 Закону України «Про охорону прав на винаходи і корисні моделі», ст. 22 Закону України «Про охорону прав на промислові зразки».

У цих статтях йдеться про дії, які не визнаються порушенням патентних прав. Зокрема, до таких випадків відносяться право попереднього користувача, використан- ня без комерційної мети, з науковою метою, в порядку експерименту, за надзвичайних обставин, використання товару, введеного в цивільний оборот та ін.

Способи використання винаходу, корисної моделі, промислового зразка наводяться в законі. Зокрема, використанням винаходу, корисної моделі визнається виготовлення продукту (виробу) із застосуванням запатентованого винаходу (корисної моделі, промислового зразка), застосування такого продукту, пропонування для продажу, в тому числі через Інтернет, продаж, імпорт (ввезення) та інше введення його в цивільний оборот або зберігання такого продукту в зазначених цілях, застосування процесу, що охороняється патентом, або пропонування його для застосування в Україні, якщо особа, яка пропонує цей процес, знає про те, що його застосування забороняється без згоди власника патенту або, виходячи з обставин, це і так $є$ очевидним.

Звертаємо увагу, що предметом винаходу (корисної моделі) може бути як продукт, так і процес. Отже, йдеться про несанкціоноване використання як продукту, так і процесу. При цьому продукт визнається виготовленим із застосуванням запатентованого винаходу (корисної моделі), якщо при цьому використано кожну ознаку, включену до незалежного пункту формули винаходу (корисної моделі), або ознаку, еквівалентну їй. А процес, що охороняється патентом, визнається застосованим, якщо використано кожну ознаку, включену до незалежного пункту формули винаходу, або ознаку, еквівалентну їй. Щодо використання промислового зразка, то виріб визнається виготовленим із застосуванням запатентованого промислового зразка, якщо при цьому використані всі суттєві ознаки промислового зразка.

Законодавець закріпив презумпцію вини у ч. 2 ст. 28 Закону України «Про охорону прав на винаходи і корисні моделі». Тож будь-який продукт, процес виготовлення якого охороняється патентом, за відсутністю доказів протилежного вважається виготовленим із застосуванням цього процесу за умови виконання принаймні однієї з двох вимог: продукт, виготовлений із застосуванням процесу, що охороняється патентом, $є$ новим; існують підстави вважати, що зазначений продукт виготовлено із застосуванням даного процесу і власник патенту не в змозі шляхом прийнятних зусиль визначити процес, що застосовувався при виготовленні цього продукту. В такому разі обов'язок доведення того, що процес виготовлення продукту, ідентичного тому, що виготовляється із застосуванням процесу, який охороняється патентом, відрізняється від останнього, покладається на особу, щодо якої $\epsilon$ достатні підстави вважати, що вона порушує права власника патенту.

Вказані законодавчі норми містять досить багато суперечливих положень. Так, новизна виробу повинна бути доведена належними доказами. Зазвичай такими доказами може бути висновок судового експерта, патентного повіреного чи висновок Укрпатенту. На нашу думку, матеріально-правова презумпція вини відповідача (потенційного порушника) не зовсім узгоджується з вимогами процесуального законодавства щодо обов'язку доказування, адже кожна сторона повинна довести обставини, які мають значення для справи i на які вона посилається як на підставу своїх вимог або заперечень (ч. 3 ст. 12 Цивільного процесуального кодексу України). 
Також не зовсім зрозуміле формулювання законодавця про «підстави вважати, що зазначений продукт виготовлено із застосуванням даного процесу і власник патенту не в змозі шляхом прийнятних зусиль визначити процес, що застосовувався при виготовленні цього продукту». Позивач повинен довести по-перше, наявність таких підстав, по-друге, неможливість визначити процес, що застосовується. На нашу думку, позивачеві складно довести вказані обставини, оскільки він не $\epsilon$ фахівцем у певній сфері технологій. Зазвичай вказані обставини слід доводити саме шляхом подання відповідного експертного висновку. Водночас законодавець не зобов'язує позивача це робити, закріплюючи презумпцію вини відповідача, і необхідність останнього доводити факт не порушення прав позивача (патентовласника).

ВГС України також наголошує на наявність такої презумпції. Зокрема, як вказано у п. 83 Постанови Пленуму № 12 від 17.10.2012 р. «Про деякі питання практики вирішення спорів, пов'язаних із захистом прав інтелектуальної власності» особливістю процесу доказування у справах про порушення прав інтелектуальної власності на винахід $є$ правова презумпція, встановлена у частині другій статті 28 Закону України «Про охорону прав на винаходи і корисні моделі». У такому разі обов'язок доведення того, що процес виготовлення продукту, ідентичного тому, що виготовляється із застосуванням процесу, який охороняється патентом, відрізняється від останнього, покладається на особу, стосовно якої $\epsilon$ достатні підстави вважати, що вона порушує права власника патенту [5]. Наголошуємо саме на «достатності» підстав щодо факту можливого порушення. Це повинен встановити суд при розгляді справи. Отже, патентовласника (позивача) звільнено від доказування факту виготовлення нового продукту іншою особою із застосуванням запатентованого процесу. Тягар доказування протилежного покладається на іншу особу, яка виготовила цей продукт (а це зазвичай $є$ відповідач по справі).

Слід звернути увагу на те, що за патентно-правовою системою охорони захист прав інтелектуальної власності надається проти будь-якого несанкціонованого використання іншою особою винаходу, корисної моделі. Такі дії вважаються порушенням незалежно від того, чи був цей винахід (корисна модель) свідомо використаний іншою особою або ці об'єкти були створені іншою особою в результаті ії власної творчої діяльності, але вже після публікації відомостей про видачу відповідного патенту про їх охорону.

У науковій літературі обґрунтовують, що для того, щоб встановити, чи підпадає спірний об'єкт під поняття, зазначене у формулі, необхідно перевірити наявність у ньому сукупності всіх ознак формули, незалежно від того, чи $є$ вони родовими чи індивідуальними $[6$, с. 5]. Тому факт використання винаходу (корисної моделі) встановлюється шляхом порівняння ознак об'єкта, який впроваджується (виробляється, використовується, реалізується) на практиці, із сукупністю ознак, наведених у формулі винаходу (корисної моделі) патентовласника [4, с. 257].

Вважаємо, що у справах про захист патентних прав у разі наявності спору між сторонами суд практично у кожній такій справі повинен призначати експертизу (безумовно, за клопотанням будь-якої із сторін, зазви- чай за клопотанням відповідача, оскільки матеріально-правова презумпція покладає саме на нього обов'язок доказування вини). Замість висновку експерта можна подати інший доказ непорушення прав позивача. Таким доказом може бути, наприклад, висновок Укрпатенту.

Угодою про торговельні аспекти прав інтелектуальної власності (ТРІПС), передбачено, що процедури, які стосуються захисту прав інтелектуальної власності, не повинні бути безпідставно ускладнені або вартість їх здійснення не повинна бути високою або супроводжуватися значними матеріальними затратами, містити безпідставні часові обмеження або невиправдані затримки. На це наголошує ВГС України у Постанові Пленуму «Про деякі питання практики призначення судових експертиз у справах зі спорів, пов'язаних із захистом права інтелектуальної власності» від 23.03.2012 № 5 [7]. Саме тому, на переконання ВГС України, питання про призначення судової експертизи повинно вирішуватися лише після ґрунтовного вивчення обставин справи і доводів сторін щодо дійсної необхідності такого призначення.

Погоджуємося з таким підходом, однак, на нашу думку, суддя не $\epsilon$ фахівцем у сфері техніки та технологій, тому він не володіє спеціальними технічними знаннями, достатніми для вирішення патентного спору. Можливо, після формування Вищого суду з питань інтелектуальної власності судді цього суду матимуть крім юридичної освіти додатково і технічну освіту, яка дозволить їм без обов'язкового призначення експертизи вирішувати окремі патентні спори. Така практика $\epsilon$ поширеною в окремих країнах $€$. Водночас такий порядок потребуватиме ще i внесення змін в чинне законодавство України.

За допомогою експертного дослідження можуть бути встановлені фактичні дані про: наявність новизни винаходу чи корисної моделі на дату подання заявки на видачу патенту або якщо заявлено пріоритет, на дату пріоритету (в порівнянні з протиставленим винаходом (корисною моделлю) або відомим технічним рішенням); наявність у винаходу винахідницького рівня, тобто чи не випливає він явно з рівня техніки (не $\epsilon$ для фахівця очевидним); відповідність корисної моделі критерію патентоздатності «промислова придатність»; наявність у формулі запатентованого винаходу (корисної моделі) усіх ознак, які були у поданій заявці [7].

У науковій літературі вказують, що для тлумачення формули винаходу застосовують так підходи: «центральний» та «периферійний». При першому підході суд намагається виявити суть винаходу з формули і опису винаходу на основі загальних знань і з урахуванням сучасного рівня техніки. Потім з'ясовують, чи дійсно у випадку, що розглядається, продукція включає елементи, що складають суть винаходу. При другому підході суд намагається визначити, яке рішення описує формула винаходу і чи дійсно рішення, яке $\epsilon$ предметом судового спору, відповідає зазначеному у формулі винаходу [8, с. 378].

Вважаємо, що справи щодо порушення патентних прав $є$ досить складними по своїй суті. У ст. 35 Закону України «Про охорону прав на винаходи і корисні моделі» наводиться орієнтовний перелік спорів, предметом яких $\epsilon$ захист патентних прав. Зокрема, це спори про: авторство на винахід (корисну модель); встановлення факту використання винаходу (корисної моделі); пору- 
шення прав власника патенту; щодо укладання та виконання ліцензійних договорів; щодо право попереднього користування; щодо стягнення збитків.

Порушення прав власника патенту можуть носити договірний і недоговірний характер. У статті було розглянуто здебільшого недоговірні порушення. Водночас підставою договірної відповідальності за порушення патентних прав $\epsilon$ невиконання чи неналежне виконання договору, на підставі якого особа отримала право на використання винаходу, корисної моделі, промислового зразка. Зазвичай, йдеться про використання вказаних об'єктів патентного права в інший спосіб, ніж це передбачено, наприклад. Ліцензійним договором, або 3 перевищенням обсягів виробництва товару тощо. Договірна відповідальність за порушення прав власника патенту може стати предметом окремого наукового дослідження.

Висновки. У законі не визначено переліку порушень прав на об'єкти патентного права, а лише вказано, що будь-яке посягання на патентні права, які визначені законом, $є$ порушенням цих прав. Закони України «Про охорону прав на винаходи і корисні моделі» та «Про охорону прав на промислові зразки» не містить ні переліку порушень, ні визначення понять окремих порушень патентних прав, що можна вважати недоліком законодавчої техніки щодо регулювання вказаних відносин. Порушення патентних прав має місце тоді коли, особа (порушник) здійснює використанням винаходу (корисної моделі) без згоди відповідного суб'єкта патентних прав (власника патенту або його правонаступника). Така згода підтверджується договором (ліцензійний договір, договір про передання виключних прав тощо) або ліцензією. Встановлена законом матеріально-правова презумпція вини відповідача не зовсім узгоджується з вимогами процесуального законодавства щодо обов'язку доказування.

\section{Література}

1. Інтелектуальне право України / за заг. ред. проф. О.С. Яворської. Тернопіль : Підручники і посібники, 2016 p. 608 c.

2. Тарасенко Л.Л. Захист прав інтелектуальної власності на винаходи (корисні моделі) та промислові зразки. Вроцлавсько-Львівський юридичний збірник. 2016. № 7. C. 247-257.

3. Кодинець А.О. Захист прав інтелектуальної власності в умовах впровадження судової реформи. Підприємництво, господарство і право. 2018. № 3. С. 9-13.

4. Тарасенко Л.Л. Вирішення спорів щодо порушення патентних прав. Часопис Київського університету права: український науково-теоретичний часопис. 2016. № 2. C. 255-259. URL: http://kul.kiev.ua/doc/CHAS16_2.pdf.

5. Постанова Пленуму Вищого господарського суду України № 12 від 17.10.2012 р. «Про деякі питання практики вирішення спорів, пов'язаних із захистом прав інтелектуальної власності». URL: https://zakon.rada.gov.ua/laws/ show/v0012600-12.

6. Кириченко Т.С. Захист патентного права на основі формули винаходу : автореф. дис. ... канд. юрид. наук : 12.00.03 / Нац. ун-т внутр. справ. Харків, 2005. 20 с.

7. Постанова Пленуму Вищого господарського суду України № 5 від 23.03.2012 р. «Про деякі питання практики призначення судових експертиз у справах зі спорів, пов'язаних із захистом права інтелектуальної власності». URL: https://zakon.rada.gov.ua/laws/show/v0005600-12.

8. Право інтелектуальної власності: Акад. курс : підруч. для студ. вищих навч. закладів / за ред. О.П. Орлюк, О.Д. Святоцького. Київ : Видавничий дім «/н Юре», 2007. 696 c.

Панасюк К. Т., аспірант кафедри інтелектуальної власності, інформаційного та корпоративного права Львівського національного університету імені Івана Франка 